\title{
Uncovering the Reasons of EFL Teachers' Unwillingness and Demotivation towards Being More Assessment Literate
}

\section{Elcin Olmezer Ozturk (D) $1{ }^{*}$}

${ }^{1}$ Anadolu University, Faculty of Education, Department of Foreign Language Education, Eskişehir, Turkey

\author{
ARTICLE HISTORY \\ Received: Feb. 08, 2021 \\ Revised: Apr. 18, 2021 \\ Accepted: May 29, 2021 \\ Keywords: \\ Assessment literacy, \\ Turkish EFL teachers, \\ Unwillingness, \\ Demotivation.
}

\begin{abstract}
The current study investigates the reasons of EFL teachers' unwillingness and demotivation towards being more assessment literate. $19 \mathrm{EFL}$ teachers working in the preparatory programs of various state universities took part in the study, and the data were collected via semi-structured interviews. Those 19 teachers were deliberately chosen from 27 teachers based on their negative utterances towards being more assessment literate in relation to the aim of the current study. The data obtained from the utterances of the participants with respect to two interview questions were transcribed, coded and labelled according to the recurrent and common themes according to the qualitative content scheme of Creswell (2012). The findings revealed that why the participating teachers were unwilling and demotivated to be more assessment literate resulted from five factors; a) seeing language assessment as an extra burden, b) the presence of testing office and materials, c) language assessment as an anxiety-provoking factor, d) institutional factors and e) rarity of ways to improve oneself. Apart from shedding light on the unwillingness and demotivation of teachers to learn more about assessment, this study also comes up with implications for language teachers and research suggestions in relation to the findings of the study.
\end{abstract}

\section{INTRODUCTION}

\subsection{Assessment Literacy and Language Assessment Literacy}

Assessment literacy (AL) "is not an initiative, not just another fad or bandwagon to jump on or off, it is a foundational and essential competency for all school leaders, teachers and students" (McCafferty \& Baudry, 2018). As is understood from the quotation, assessment literacy is seen as a "sine qua non for today's competent educator" (Popham, 2009, p. 4), and it is not an extra feature to possess; rather, it is a basic component of education. The definitions of assessment literacy abound in the literature. Stiggins (1991), coining the term, defined assessment literacy as teachers' skills in the use of assessment. Falsgarf $(2005$, p. 6) stated that it "is the ability to understand, analyze, and apply information on student performance to improve instruction". Additionally, for Popham (2018), it is the understanding of basic and important concepts in assessment.

\footnotetext{
*CONTACT: Elcin Olmezer Ozturk \ elcinolmezerozturk@anadolu.edu.tr $\risingdotseq$ Anadolu University, Faculty of Education, Department of Foreign Language Education, Eskişehir, Turkey
} 
Newly coined term rooted in assessment literacy is language assessment literacy (LAL). Though it has similar features with assessment literacy, as it is specifically on language, it also has different characteristics. Davies (2008), with a focus on language, stated that LAL consists of three parts that are knowledge, skills and principles. For Malone (2013, p. 329), language assessment literacy is "language teachers' familiarity with testing definitions and the application of this knowledge to classroom practices in general and specifically to issues related to assessing language". Lastly, Inbar-Lourie (2008, pp. 389-390) defined this term as "language assessment knowledge base comprises layers of assessment literacy skills combined with language specific competencies, forming a distinct entity that can be referred to as language assessment literacy". As is seen, LAL and AL have similar features, both requiring a teacher having sound knowledge in assessment; yet, LAL also requires a language teacher to be knowledgeable in both assessment and language, and language-related assessment.

\subsection{The Necessity of Assessment Literacy and Assessment Literate Teachers}

Assessment should not be seen as a product or outcome only; rather, many strategies and processes helping learners become better learners and educators are involved in assessment (McCafferty \& Baudry, 2018). Though each and every stakeholder in education is into assessment for various reasons, it is the teachers who have major roles in assessment. Language teachers have this role of assessment as a part of their professions (Mertler, 2003), and also Stiggins (1991) argued that teachers spend $50 \%$ of their instructional time with assessmentrelated activities. What teachers have to know related to assessment varies such as reliability, validity, designing tasks, alternative assessment, scoring, and it is for sure that each and every teacher needs a dose of assessment literacy (Popham, 2011).

When assessment-literate teachers "make educational decisions based on appropriate assessment-elicited evidence, the resultant decisions almost always will be more defensiblemeaning, more likely to improve students' learning" (p. 2), and when good decisions are made, it means avoiding mistakes (Popham, 2018). Moreover, when more valid decisions are made, it is more possible to appeal to learners' needs more and adapt instruction (Shepard, 2000). On the other hand, when teachers lack adequate knowledge related to assessment, they could make certain mistakes that could be grouped under three categories that are "using the wrong tests, misusing results of the right tests, and failing to improve instructionally useful tests" (Popham, 2018, p. 8). To avoid these kinds of mistakes, assessment literate teachers are needed in teaching and learning process because the power of assessment is rooted in the knowledge of teachers in assessment (Calderhead, 1996).

In spite of the importance of assessment literate teachers in instruction, teachers have limited competency in assessment (Popham, 2018), and teachers are not assessment literate (Alderson, 2005; Mertler and Campbell, 2005). Many teachers do not feel themselves ready for assessment-literate activities including both pre- and in-service teachers. Pre-service teachers stated that they did not expose to sufficient and qualified education in assessment, and many in-service teachers expressed that they are not adequately equipped with assessment knowledge (Plake, 1993). Stiggins (2010, p. 233) drew attention to this problem by stating that "assessment illiteracy abounds".

\subsection{Related Studies}

Research into language assessment literacy "is still in its infancy" (Fulcher, 2012, p. 117); however, the number of the studies investigating assessment literacy and language assessment literacy is increasing day by day. While some studies focused on the needs of teachers as the conductors and designers of assessment-related tasks (Vogt \& Tsagari, 2014; Volante \& Fazio, 2007), some examined language assessment literacy of teachers (Ölmezer-Öztürk \& Aydın, 2019; Volante \& Fazio, 2007). Thus, various aspects of assessment literacy have been 
investigated in several studies.

To start with, Volante and Fazio (2007) studied with 69 pre-service teachers, and their assessment knowledge and needs for assessment were investigated. Though the participants stated that they had taken an assessment course, they still needed to learn more about assessment. The findings also indicated their low level of confidence in assessment-related tasks. In a similar study with different stakeholders as participants, O'Loughlin (2013) examined university administrators' assessment needs since they were responsible for admission decisions. The administrators from two universities in Australia received a survey including questions related to IELTS use, evaluation, etc. The findings revealed that the administrators needed to be more assessment literate and educated for the valid and reliable interpretation of test scores. On the other hand, in Vogt and Tsagari (2014), 153 teachers from seven European countries were asked about their needs in LAL in three aspects that are classroom-focused language assessment, purposes of testing, and content and concepts of language assessment. The results demonstrated that the teachers were not competent enough in some areas such as self and peer assessment, portfolio assessment, reliability, validity and using statistics.

In addition to the studies focusing on LAL needs of teachers, some others investigated the assessment literacy levels of teachers or their perceptions of it. For instance, Lam (2015) focused on the overall language assessment training in five Hong Kong institutions, and preservice teachers' perceptions of their LAL development. The findings showed that there was insufficient support to foster LAL, and the training for LAL was inadequate based on the perceptions of the participants. Similarly, Baker and Riches (2017) aimed to examine whether a series of workshops contributed to LAL development of 120 Haitian high school teachers. The data were collected via feedback on drafts of revised exams, survey with teachers, and teacher interviews and the results demonstrated that LAL development of the teachers was clear after these workshops, and their LAL levels increased in creating reading comprehension questions, in learning about reliability, validity, and practicality, and increased attention of the connection between teaching and assessment. In another study conducted in Turkish EFL context, Ölmezer-Öztürk and Aydın (2019) investigated language assessment knowledge of 542 language teachers working in higher education by using a scale they developed. The findings revealed that the participant teachers were not assessment literate, and the teachers were the most knowledgeable in assessing reading whereas they had the lowest score in assessing listening.

\subsection{The Present Study}

As assessment literate teachers play crucial roles in the efficacy and appropriacy of assessmentrelated activities, the importance of having assessment literate teachers in education is stressed in the literature (Alderson, 2005; Leung, 2014; Malone, 2013; Popham, 2006). Yet, the studies in the literature demonstrated that both pre- and in-service teachers do not feel themselves competent enough and they are not self-confident and knowledgeable in assessment-related activities due to their lack of assessment literacy (Hatipoğlu, 2015; Tsagari \& Vogt, 2017). Though few in number, there exist certain studies focusing on the needs of EFL teachers in relation to language assessment (Fulcher, 2012; Inbar-lourie, 2008; Malone, 2013; Volante \& Fazio, 2007), language assessment literacy levels of EFL teachers (Tao, 2014), the effectiveness of trainings on their language assessment literacy levels (Campbell, Murphy, \& Holt, 2002; Mertler, 2009), and language assessment knowledge of EFL teachers (Ölmezer-Öztürk \& Aydın, 2019; Şahin \& Hatipoğlu, 2019). As a common point in these studies, there is a special emphasis on the notion that language teachers lack a certain level of language assessment literacy and they need some training on it. However, they do not present the background and reasons for this problem. In other words, the studies in the literature basically describe the 
situation by showing how assessment illiterate EFL teachers are and what they need to become more assessment literate. Besides, compared to the number of aforementioned studies, there is a paucity of research focusing on the reasons why language teachers are or feel themselves incompetent in language assessment. Even though, as demonstrated, many in-service teachers are assessment illiterate, why many teachers do not take action and are not willing and motivated enough to be more knowledgeable in language assessment have not been the foci of any studies so far to the best knowledge of the researcher. Examining the underlying reasons of their unwillingness and demotivation with respect to language assessment is of primary concern, because when the underlying reasons of their unwillingness and demotivation have been uncovered, then better conditions and opportunities could be provided for the teachers to be more assessment literate. Within that scope and purpose, the following research question is asked throughout the study.

What are the underlying reasons of EFL teachers' unwillingness and demotivation to being more assessment literate?

\section{METHOD}

\subsection{Research Design}

Aiming to identify the main reasons behind EFL teachers' unwillingness and demotivation to be more assessment literate, the current study employs a basic qualitative research perspective which is "concerned with subjective opinions, experiences and feelings of individuals and thus the explicit goal of research is to explore participants" views on the phenomena being studied" (Dörnyei, 2007, p. 38). Since the major focus of the study is to uncover opinions and experiences of participating teachers on the research matter, their language assessment literacy, a qualitative perspective is followed throughout the study.

\subsection{Research Context}

The research context is the preparatory programs of state universities in Turkey. Language teachers are responsible for teaching English to learners in this program, and while some programs offer English courses in an integrated way, some divide the courses into skills such as reading, writing, speaking and listening. There exist certain offices in these programs such as testing office, material development office, and curriculum office. Teachers take part in these offices either willingly or upon the will of their managers. Testing office members have various duties, and what they are responsible for may differ based on the institutions since there is not a determined program or schedule for testing office members of the institutions in Turkey. Owing to this, it is usual to come across different and various performances of the institutions. Moreover, to exchange ideas and determine assessment-related tasks, testing office members gather and decide on certain issues related to assessment such as the type of exams, the items to be asked in the exams, scoring, etc.

\subsection{Participants}

The participants include the teachers working at preparatory programs of nine different state universities. 19 teachers in these programs are the participants of this study, and none of them is a member of the testing office in their institutions. Convenient sampling was preferred for this study. At the very beginning, 27 teachers were sent a question asking for whether they had a positive attitude towards being more assessment literate and whether they were making efforts for this. Eight of them stated that they were eager to learn more about language assessment and trying hard to be more assessment literate teachers. As these eight teachers had a positive attitude towards language assessment, and the focus of the study is to find out the reasons of negative attitudes towards it, they were excluded from the actual study. Based on their negative stance, 19 teachers were interviewed by either skype or face-to-face semi-structured questions. 
Out of these 19 teachers, 11 were females and eight were males. Besides, their ages ranged from 28 to 47, and their years of experience in teaching varied as well. Their educational background was also various, and they were the graduates of English Language Teaching Department and English Language and Literature. Finally, different universities were preferred so as to hinder the possible problems that may come out because of the contextual factors.

\subsection{Data Collection Process}

In semi-structured interviews, the teachers were asked two questions which were prepared by the researcher beforehand in the scope of the study. The questions were checked by two colleagues for clarity and wording. Moreover, two academicians in ELT were asked for their opinions regarding the content of the items and whether they served their purposes or not. The questions were in Turkish to be able to get more and richer answers from the participants and help them feel themselves more relaxed while answering without the interference of the target language. The questions asked in the interview are as Table 1:

Table 1. The interview protocol.

$$
\text { QUESTIONS FOR THE INTERVIEW }
$$

1. In the first phase of the study, you stated that you had negative attitudes towards language assessment, and you were not making any/many efforts towards being more assessment literate. What are the reasons of your negative attitude towards language assessment?

2. Do you have any negative memories or experiences related to language assessment? What is this/What are these?

\subsection{Data Analysis}

The qualitative content analysis scheme of Creswell (2012) was used to analyze the data obtained from 19 participant teachers. All the answers of the participants were transcribed first, and then grouped into codes based on their common and recurrent ideas in the transcriptions. Rooted in these codes, certain themes came out, and these themes were presented in frequencies. Data analysis process is highlighted in the following Figure 1:

Figure 1. Content analysis scheme.

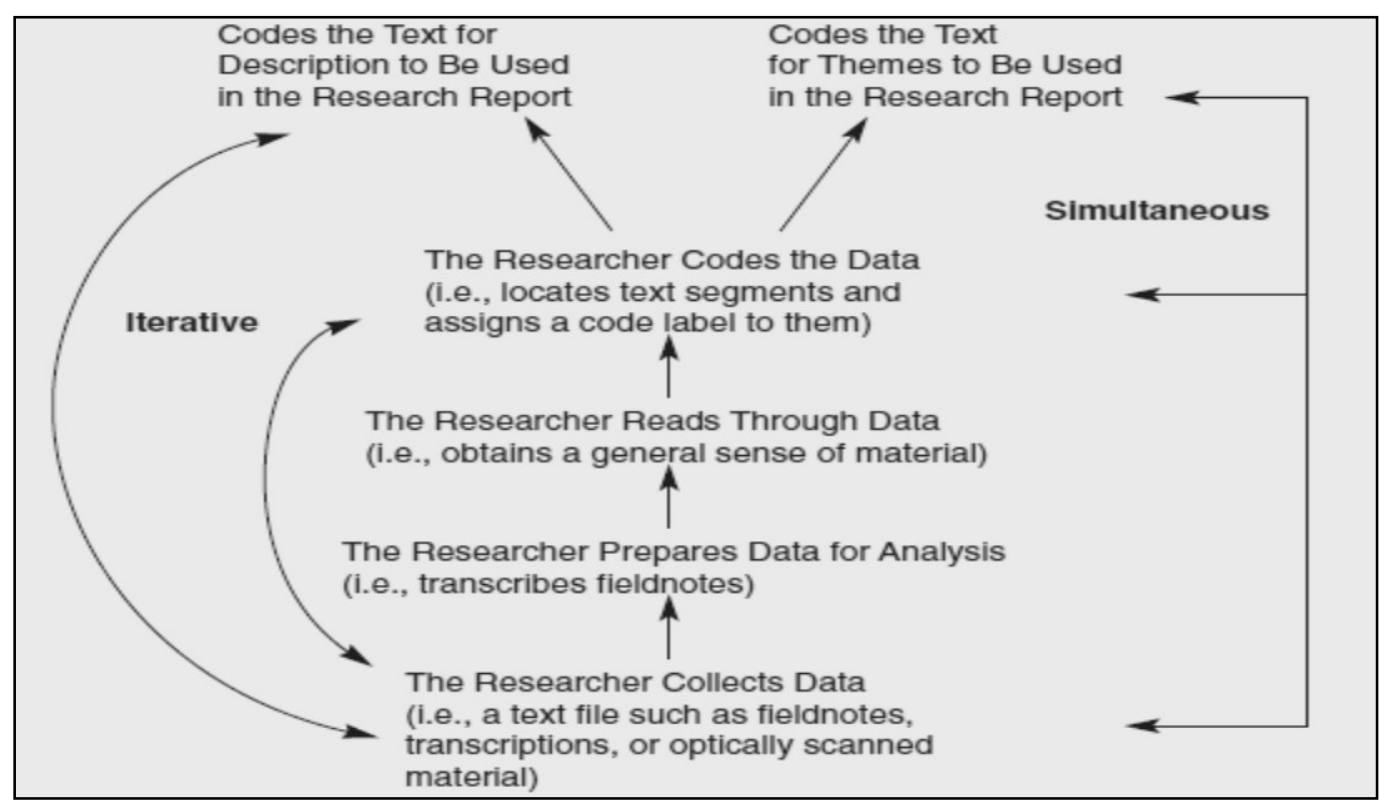




\section{FINDINGS}

The research question of the current study aimed at finding out the reasons of EFL teachers' unwillingness and demotivation to being more assessment literate. The following Table 2 demonstrates the themes and codes that came out based on the investigation of the reasons of their unwillingness and demotivation with respect to the frequencies.

Table 2. Themes and codes derived from the participants' answers.

\begin{tabular}{l|l}
\hline THEMES & CODES \\
\hline LA as an extra burden & Requiring extra efforts and time (x13) \\
& Not compulsory (x9) \\
& Not heavily focused in pre-service education (x8) \\
\hline The presence of testing office and materials & Testing office's duty, not mine (x14) \\
& The presence of ready-made materials (x9) \\
\hline LA as an anxiety-provoking factor & Not feeling self-confident (x10) \\
& Too much terminology (x6) \\
& Requiring statistical knowledge (x5) \\
\hline Institutional factors & Their colleagues and students' harsh criticisms (x14) \\
& Absence of support and no appreciation (x10) \\
& Rarity of teachers who are role-models and competent \\
& in LA (x7) \\
& Having the same responsibility with everyone (x5) \\
& Objection to changes and novelty in exams (x4) \\
\hline Rarity of ways to improve oneself & Books focusing on assessment in general (x6) \\
& Not enough conferences specifically focusing on as- \\
& sessing language skills (x5) \\
\hline
\end{tabular}

After the analysis of the data, many codes were identified, and as the next step, these codes were grouped under common themes. The analysis of the data revealed five themes based on the answers of the participants that are language assessment as an extra burden, the presence of testing office and materials, language assessment as an anxiety-provoking factor, institutional factors and rarity of ways to improve oneself. To start with the first theme, the teachers perceived language assessment as not a part of their teaching, but an extra duty or qualification. 13 teachers expressed that language assessment is a demanding field which requires many efforts and hours and days of studying to be competent in.

T7 stated that,

"Assessment is a broad field, and there are many sub-topics of it. To be more assessment literate, I have to study a lot-though I am studying for my courses-, and make many efforts for these."

T16 expressed that,

"Our duty goes on outside the school as well. When I get home, I check my students' assignments most of the time and give written feedback to their works. Even though these could be regarded as a part of the assessment, I am just giving feedback to my learners. As I do not have much time for my professional development, I cannot find any time to go through the literature on language assessment and learn more."

In addition to these, T3 mentioned that,

"Whenever I have time, I do my best to improve myself as a teacher such as discovering books on teaching and interesting and motivating activities for students, but not related to assessment. I feel teaching is the primary job of me, and I can survive with the knowledge I have related to assessment." 
One of the participant's utterance (T4) made it clear that she perceived teaching and assessment as too different concepts and not interconnected. She stated that,

"My primary job is to teach, not to assess. I am already busy with teaching, and I have more than 20 hours for teaching per week. I have to prepare materials for the courses, cover the books and select the most appropriate and motivating ones for my students. At the same time I have to keep up with the curriculum. These all take time, and under such conditions, I have no time to be more knowledgeable in assessment."

Along with requiring many efforts and time, nine teachers added that to be competent in assessment or to be assessment literate is not a must for teachers. T3 mentioned that "he could survive with the knowledge he has related to assessment", apart from him, T15 stated that,

"What I know is sufficient for me. I am not designing any exams, and what I am expected to do as a teacher is just to check my students' assignments- which is mostly related to grammar and organization- and give feedback to them. Thus, I do not feel the necessity to be better in language assessment."

T2 voiced that,

"Before we, as teachers, get these positions as teachers at university, some of us are asked theoretical questions about classroom management, students and teaching methodology. Some are asked questions about how to teach an example grammatical unit, some are asked the differences between certain confusing grammatical rules, etc. Yet, I have not heard of a teacher who has been asked any questions about language assessment, how to assess learners best, how to score, or how to design assessment-related tasks. That is, while I was studying for the exam to get my position in my institution, I covered many books related to teaching and learning, but not even a book on assessment."

Furthermore, T8 added that,

"To be a testing office member does not mean that you are good at assessing learners or you are very knowledgeable in this field. If I am willing to take part in testing office, I then could be a member of it. Also, there is no prerequisite knowledge to have a duty in this office. What I intend to say is that even if when you are having roles in your institution as assessors, your background knowledge in assessment is not important most of the time. For me-non-testing members-, it is naturally not a must as well because I am not having roles in exams."

Finally, eight teachers expressed that language assessment is ignored in pre-service education as well, if it is of primary importance, it should be given more emphasis throughout pre-service education. In relation to this, T12 stated that,

"For instance, in practicum in my university years, we taught English to learners, we designed materials, we tried to do our best for classroom and time management, but we did nothing related to language assessment. I did not see any sample exams, and I had no idea how the students were assessed."

Another teacher (T7) expressed that,

"In pre-service education, we had three different methodology courses that were how to teach grammar, how to teach speaking and writing and how to teach listening and reading, but we had only one course in assessment which we took in our fourth year. Fourth year was too late to learn about language assessment, and we were very busy with preparing lesson plans in practicum; thus, that course was not very beneficial for us."

Opposed to the participants taking language assessment course in their pre-service education, T9 voiced that,

"In pre-service education, we did not have a standalone language assessment course, not even assessment in general. LA was not given enough importance in pre-service education; so, my background is not good enough in relation to language assessment. I do not have any intrinsic motivation to learn more for a subject which is neglected in pre-service education as well." 
Second theme is the presence of testing office and materials. 14 teachers mentioned that assessment-related activities are carried out by testing office, and they are responsible for language assessment. Besides, nine teachers stated that there are ready-made tests and questions that could be used for assessment purposes. Related to these, one participant (T1) uttered that,

"Every teacher has a duty in the institution, and the ones in testing office are responsible for assessment. It is their job, and as I am not a member of testing office, I do not need to be more proficient and knowledgeable in language assessment. Yet, the ones in testing office have to do this."

Another teacher (T10) verbalized that,

"Testing office members gather and hold long-lasting meetings, they also design questions and negotiate them. If I were in testing office, then I would feel the pressure on my shoulders to search and learn more about language assessment. To do this, I would look for the books and exchange ideas with my friends working in other preparatory programs in relation to their practices. But, now as testing office members prepare everything for me, and what I have to do is to invigilate while students are seated in an exam."

One more example is related to the ready-made materials, and T5 stated that,

"There exist ready-made questions related to each skill, and these questions are given to the teachers together with their teacher books. These questions are designed by knowledgeable people and they spend a lot of time, and they go through many stages. Thus, is there a real need for designing questions again and again? I guess not."

Third theme is language assessment as an anxiety-provoking factor. 10 teachers expressed that they do not feel confident enough in language assessment. Six participants thought that there is too much terminology in language assessment, and partly complained about them. Finally, five of the teachers uttered that this field requires statistical knowledge, and a teacher has to be competent in statistics as well. T3 confessed that,

"I feel myself very competent in teaching-related subjects; however, when it comes to language assessment, I get stuck. What I know is not enough to regard myself as an assessment literate teacher. Since I am not self-confident enough, I get more anxious when I have to engage with assessment-related tasks. I cannot even concentrate on what I am doing. So, it is like a chain.”

T2 mentioned that,

"Assessment is a field with too many diverse views; thus, one cannot say an assessment-related task should be done in a certain way most of the time. There are pros and cons of many issues, and due to this situation, I cannot assure myself by saying that what I am doing is totally true. These diverse ideas lead me to be insecure about what I know which directly results in my lack of confidence in language assessment."

Another teacher (T1) complained about the existence of too many terms stating that,

"Indeed, I am familiar with some kinds of tasks in assessment. But, when I have a look at the books, I come across their names-in other words, terms. Though I may be making use of certain things, I am not very good at remembering their names. Hence, I try to memorize the terms that are too many to memorize, by the way. This memorization process drives me crazy, and I get really stressed."

T13 voiced that,

"Whenever I open the first page of any books on language assessment, I see the pages loaded with too many terms such as reliability, validity, and their types, etc. They are crucial as well, but seeing all the terms one after another makes me scared, and also anxious."

T15 also said that,

"Assessment goes hand in hand with statistical knowledge. You have to make calculations, and to be able to do so, you have to have some background statistical knowledge. When I am busy with all the numbers, it is like mathematics and I cannot get the joy of assessment. For instance, what I want to do is only to design questions. I do not want to calculate mean, median, etc. I feel 
as if it was not my business. But, you cannot just design questions without including statistical calculations."

Next theme is institutional factors that were mentioned by many teachers during the interviews. A lot of participants gave some reasons for why they did not want to be more assessment literate, and the existence of certain negative feelings and situations about language assessment were found to be related to their institutions. 14 teachers stated that their colleagues' and students' harsh criticisms were the reasons for why they were not very willing and motivated to be more assessment literate. 10 participants expressed that there is no support and appreciation for the teachers who are into language assessment. Furthermore, seven teachers mentioned that the number of teachers who are role-models and competent in language assessment is not enough. Five of them complained about the fact that the ones who have assessment-related duties have the same responsibility with the ones who have no extra office duties. The last one is four participants told that there is an objection to changes and novelty in the designation of exams. Some quotations related to the aforementioned codes are as follows: To start with, T4 stated that,

"I observe that people are so cruel to the teachers who are in testing office. Students always complain about the quality of the questions and they keep saying that some of the questions are false or do not have the right answers in the options. Let alone the students, teachers in my institution always find a way to imply testing office members that the topic in writing part is not very good or the reading passage is full of unknown words or too easy for students to give correct answers. Whatever they do, people find a way of complaining about the work they have done."

In parallel with the previous quotation, T6 expressed that,

"One of my friends is a member of testing office. She once told me that she did not even want to go to the canteen to get some tea in the break, because the teachers who came across her in the canteen complained about the questions all the time. She also stated that she gave up drinking tea because of those kinds of teachers murmuring a lot."

T10 shared a memory as well about these criticisms:

"My roommate was in testing office. One day, just after the exam, a teacher rushed in our room and said that the total of the points did not make a hundred in total with a high pitch of voice. My roommate was trying to be calm saying that we all checked these things again and again, let me check it once more. Then, my roommate counted the points and the total was a hundred. The reaction of the teacher was only "Oh, I miscounted then!". This example was a good indicator of how other teachers in the institution were unfriendly and intolerant to the teachers in testing office rather than appreciating them."

In relation to the second code, $\mathrm{T} 1$ uttered that,

"As far as I can see and observe, I can say that there is too much to do for testing office members, and nobody helps them just because they are not in this office officially. Some periods are full of work for them, for instance at the beginning and end of the term; but, no support is given to them by the management and the other teachers as well. They are all alone"

T3 mentioned that,

"I do not want to be engaged with language assessment since if the others hear about my interest, then I will be for sure chosen for testing office which is not very good for me. The reason is nobody appreciates what testing office members do, and they all ignore their efforts such as long meetings, negotiations, editing processes, etc."

The next code is the rarity of role-model teachers, and in relation to this, T11 uttered that,

"The problem is that the teachers in testing office are not more competent and knowledgeable than us, except for one or two teachers. The fact that a teacher has a testing office duty does not mean that I can consult that teacher when I have a question about language assessment."

About the responsibilities, T14 stated that, 
"Testing office members and non-testing members have the same hours of teaching per week. In other words, I teach and then I leave the school; however, they have also testing duties apart from teaching. They have to teach the same hours as me which is surprising. Thus, in our institution, being a testing office member is not given enough value. It would be better if testing office members are given some incentives such as decreasing their workload, or sending them to conferences, etc.

T8 working at a different institution from the previous participant said that,

"In our institution, testing office members teach less hours compared to non-testing teachers. At first, it may sound good; but, they teach two hours less which does not decrease their workload at all during the week."

Final code is teachers' not welcoming changes and novelty. With respect to this, T9 mentioned that,

"Once, I was in testing office and read a lot about language assessment; as a result, I learnt many things and saw that some of our practices were not okay. When I voiced this in one of the meetings, all of the members objected to my idea stating that they had already ready-made exams which were controlled and corrected many times up to that time, and there was no need for the things to be mixed up. I was shocked, and I had tons of memories like this unfortunately. Then, I gave up reading more about language assessment, because learning more did not contribute positively to the practices in my institution. If I cannot make use of the knowledge I have regarding language assessment, and cannot implement them in my institution, what is the use of being more assessment literate?"

In parallel to what T9 uttered, T14 said that,

"Once I was reading a book, I read something about language assessment, and I shared it with testing office members believing that they would appreciate it and would make use of that practice in the following exams. Unfortunately, they told me that they had some fixed exams, and they did not want to make big changes on them. Moreover, they expressed that their practice was totally true though I showed them the related parts in the book."

The last theme is the rarity of ways to improve oneself. Six teachers focused on the absence of books specifically designed for language assessment, and five teachers mentioned that there exist not enough conferences which they can attend and learn to the point practices related to language assessment. Here are some quotations of the participants:

T12 expressed that,

"There are many books in the literature related to assessment; but, when it comes to language assessment and assessing skills separately, there are very few books. They all refer to the first published books, as well-thus, including nearly the same information."

Another teacher (T6) stated that,

"All the books start with very general terms, and give some statistical information. Thus, it is not very easy to find a book that solely focuses on language assessment and the common practices that will help teachers use in their classrooms and exams. There should be more books covering practical uses of assessment."

Similar to the books, T8 complained about the conferences by saying that,

"Most of the conferences have many sub-topics, and one of them is assessment. Thus, it is not very easy to find a conference in which there are many speakers who are expert in language assessment and deliver a speech on language assessment that is full of practical issues. Rather, there are some conferences on assessment in general, but the topics are too technical and specific; hence, it does not make any sense whether you attend those or not."

\section{DISCUSSION}

The current study shed light on this issue by uncovering the factors leading language teachers to be reluctant and resistant to language assessment literacy. The participants were 19 teachers 
working at preparatory programs of state universities, and they did not have duties in testing offices in their institutions. Out of 27 teachers who were sent a question asking for whether they had a positive attitude towards being more assessment literate or not, 19 of them stated that they did not feel very eager to learn more about language assessment, and these participants provided the data for the current study. They were asked three questions, and their answers to these questions were transcribed and code-labeled by the researcher and also a colleague with a Phd in ELT. The data revealed that why the teachers had some resistance to be more assessment literate stems from five main issues that are language assessment as an extra burden, the presence of testing office and materials, language assessment as an anxiety-provoking factor, institutional factors and rarity of ways to improve oneself.

The themes derived from the obtained data were language assessment as an extra burden, presence of testing office and ready-made materials, language assessment as an anxietyprovoking factor, institutional factors and rarity of ways to improve oneself in regard to language assessment. To begin with the first theme, the participants stated that language assessment requires extra efforts and time, it is not compulsory to be more assessment literate, and it is not heavily focused in pre-service education. With respect to language assessment's requiring extra efforts and time and being not compulsory, Purpura (2016, p. 191) stated "rather than seeing assessment as an organic part of applied linguistics, L2 assessment is still often viewed as an afterthought, or as a craft". Besides, Stiggins (1995) drew attention to the fact that language assessment cannot be regarded as an extra thing for teachers since it is an inevitable part of their jobs. What is more, Popham (2006, p. 85) touched upon the necessity and importance of language assessment by saying that "Today, more than ever, assessment plays a pivotal role in the education of the students. That's why educators - and everyone else who has an interest in education- need a dose of assessment literacy". As is seen, assessment literacy is not only necessary for teachers who have an interest in assessment, but also anyone who is an educator. Upon this importance, Mertler (2002) stated that all duties of teachers are important, and should be given great care; but, the most important duty of a teacher is the assessment. Katz (2012) also warned all language teachers that language assessment should not be seen external to teaching and learning; rather, language assessment and instruction cannot be separated and they have to go hand in hand for an effective instructional process (Malone, 2013). As is understood, although the literature presents assessment and learning as a strongly connected process that should go hand in hand, the opinions of the participants show that teachers may perceive assessment as an extra work or duty not closely related with teaching and learning process. This perception of "assessment as an extra burden", which might be originating from several reasons such the lack of supervision at the institutions, turns to be a leading factor in teachers' unwillingness to be more assessment literate.

In relation to the pre-service education, in parallel with these findings, Mertler (2005) and Stiggins $(1991,1995)$ also stated that education policies are not assuring that the pre-service teachers get adequate training in language assessment before they start their professions. This subject field is still ignored in professional development programs. Furthermore, the participants expressed that they had either no separate language assessment course or just one course covering all the assessment of skills and assessment in general superficially. Schafer (1993) also maintained that half of the teacher education programs do not have a standalone course in language assessment, and added that the ones having the course does not give enough importance to the assessment of each and every skill. For instance, not enough emphasis is given to the teachers for the development of their language assessment literacy in North America (Coombe, Troudi, \& Al-Hamly, 2012), and in the similar vein, in our context, Turkey, professional development of teachers is seen as more valuable and given importance day by day, but not in terms of language assessment. Professional development programs are becoming more popular and common day by day, but they include the development of teachers 
in terms of their teaching skills. Assessment is still not a part of these programs. This issue was raised by many researchers coming up with the same conclusion that pre-service education should not be restricted to only one course in pre-service education (Hatipoğlu, 2015; Herrera \& Macias, 2015; Ölmezer-Öztürk \& Aydın, 2019; Popham, 2009). In their study, Mede and Atay (2017) found out that $62 \%$ of the participants had a separate language testing and evaluation course in pre-service education, but they found it very insufficient.

Next, in relation to the second theme that is the presence of testing office and ready-made materials, the teachers voiced that language assessment is testing office's duty, not theirs and there already exist ready-made materials to be used for language assessment. In the preparatory programs in Turkey, there are various offices and each of them has a different focus and duty. One of them is testing office, and only the teachers who are the members of testing office are responsible for designing tests and assessment-related tasks, and the teachers who are not the members of testing office are only responsible for invigilating. As is clear, if they do not have the intrinsic motivation to be more knowledgeable in language assessment, they do not need to learn more about assessment. All the things related to language assessment are prepared by testing office, and all the teachers are given the necessary information by this office again. Some teachers may find not having to design any questions easy, and no effort is made as well. In relation to this, Coombe, Troudi, and Al-Hamly (2012) stated that some teachers cannot keep up with the recent changes in the field of language assessment; thus, they just ignore their duties as assessors, and let the others do these duties. As is obvious from the utterance above, some teachers may not feel the necessity to be more knowledgeable, and find it easy when the works are done by more responsible ones.

To go on with the third theme which sees language assessment as an anxiety-provoking factor, it was mentioned in the data of the teachers that they were not feeling themselves self-confident enough in language assessment, there is too much terminology to be covered in this field, and it requires them to know statistical knowledge to be competent in it. This finding is in line with what Coombe, Troudi and Al-Hamly (2012) stated in relation to language assessment that teachers attach unpleasant feelings to language assessment. Moreover, Jacobs and Chase (1992) voiced that the teachers are not very happy while carrying out their assessment-related activities because of the fact that language assessment is seen as one of the unpleasant duties of teachers. In the same vein, Stiggings (1995) maintained that the most important barrier to assessment literacy by teachers is fear of assessment, and this fear is formed owing to the unpleasant experiences teachers had when they were students. Besides, Herrera and Macias (2015) stated that because most of the teachers do not like the assessment part of their jobs, they design test that are not very effective in terms of classroom assessment, and their fear of assessment leads them not to be able to be more assessment literate (Mertler, 2002). Another point leading teachers to unpleasant feelings is the existence of too much terminology and statistical knowledge. This issue was stated by McNamara and Roever (2006) who indeed was drawing attention to the trainings that are all full of applied psychometrics. Maybe owing to this reason, when teachers hear language assessment, one of the first things that comes to their minds is statistics. In other words, they relate language assessment to statistics.

Fourth theme is institutional factors in which the participants expressed that teachers engaging with language assessment in their institutions get harsh criticisms from their colleagues and students, there is no support for these teachers who make efforts to be more assessment literate, there is scarcity of teachers in their institutions who could be regarded as role-models for them and more knowledgeable than them, and finally these teachers trying to be interested in language assessment or testing office duties have the same responsibility with other teachers. What Coombe, Troudi, and Al-Hamly (2012) mentioned in their article is in parallel to the findings of this study, and they stated that some heads do not reduce the workload of teachers who deal with assessment-related tasks, and do not support these teachers. Banat (2018) also 
stated similar ideas related to the institutions, and added that though common in institutions, assessment does not always rely on fair and valid basis, and owing to this reason, poor assessment in institutions does not always result from the assessment illiterate teachers, but the heads and institutional policies may be leading to inappropriate measures. The possible reasons of these negative attitudes could be the idea that language assessment is not seen as a must which each and every teacher should get involved in. Since both heads and teachers have similar ideas related to language assessment, they just tend to ignore the efforts of teachers who are actively involved in assessment-related tasks. In a similar vein, the workload of teachers is not reduced and they have the same teaching hours with other teachers, because what they do is not appreciated by others, and language assessment as a field is ignored.

The last one is the rarity of ways to improve oneself in terms of language assessment. The teachers said that there are not enough books which are specifically designed for assessing language skills and give practical information to teachers. Rather, they are mostly loaded with terminology and general information about language assessment. One more thing they stated is that the number of conferences specifically focusing on language assessment is not many in number, especially in our country. In the same vein, Coombe, Troudi, and Al-Hamly (2012) expressed that one of the barriers to assessment literacy is insufficient resources, and they suggested that to have more assessment literate teachers, online assessment resources should be available to all language teachers.

\section{CONCLUSION}

Assessment literacy is not an option or an extra qualification for today's language teachers in such a world where more and more scholars focus on the necessity and importance of assessment literacy for all teachers. As stated by Purpura (2016), it is not an extra craft, but the indispensable part of teachers' jobs. This study, along with touching upon this term, most specifically investigates the reasons of language teachers' resistance and unwillingness to being more assessment literate. The literature shows that there are many studies displaying that many in-service teachers do not feel themselves competent enough to carry out their assessmentrelated tasks, and these teachers do not feel ready for their professions (Mertler, 2003; Plake, 1993; Popham, 2006; Stiggins, 1991, 2010). One reason for this is seen as the insufficiency of pre-service education. However, learning and being more equipped with knowledge may stem from many factors, let alone pre-service education.

For language assessment taking extra efforts and time, the participants voiced that language assessment is not compulsory and a teacher does not have to have any skills or trainings to start the profession, and this field is not heavily focused in pre-service education. Another issue raised by the teachers was the presence of testing office and ready-made materials. Owing to these reasons, they thought that assessment-related tasks should be carried out by the teachers who are the members of testing office, and it is not their duty. Furthermore, there are already ready-made materials; thus, it was found awkward and unnecessary by some teachers to design assessment tasks again and again, and not using ready-made materials. Just using the readymade materials as they is a way of assessing learners; hence, these teachers did not care about being capable of designing them. Moreover, the teachers stated that they feel anxious about language assessment because they do not feel self-confident enough, there is too much terminology and it requires statistical knowledge. Institutional factors were found to be a factor leading the teachers to be more assessment illiterate. They said that there are harsh criticisms by both teachers and students, there is no support or appreciation, there are not enough teachers who could be role-models with the help of their knowledge in language assessment, the testing office members have the same workload with other teachers which the participants found not fair, and changes and novel ideas in the exams are not very welcome by many teachers. The last issue was the rarity of conferences and books solely focusing on the language assessment 
and assessment of each skill. These results yielded that why the teachers were not motivated enough to be more equipped with language assessment knowledge is a multi-faceted issue, and there exist many factors leading them to resistance and unwillingness.

\subsection{Implications and Future Research}

For the implications of the study, to start with, language assessment should be covered in at least two separate courses including practices as well in pre-service education. In practicum, pre-service teachers should be responsible for not only teaching and preparing lesson plans but also assessment parts of teaching. If language assessment is dealt with in detail, and the practice is included in practicum; then the graduates will feel themselves more self-confident in terms of language assessment, and also will have a better understanding about the necessity and importance of this field. Secondly, awareness raising activities that will help teachers gain the importance of assessment in learning and teaching should be organized in instituions, and after that teachers should have more opportunities to receive trainings and workshops on language assessment. The idea that language assessment is not an extra qualification for a language teacher should be transmitted to each and every teacher throughout these trainings and conferences. Last but not the least, the teachers who actively get involved with assessmentrelated activities should be encouraged, and they should be provided sufficient resources and their workload should be reduced.

In terms of research directions, first of all, a detailed and more extended investigation of EFL teachers' perspectives on language assessment literacy is needed. Identification of such a descriptive picture among EFL teachers that will explore their perspectives, opinions and need on language assessment will also help policy makers make better decisions on teacher training and language assessment policies. Besides, the short term and long term effectiveness of trainings and workshops organized by instituions should also be investigated for the betterment of such practices.

When it comes to the limitations of this study, firstly, the data revealed 19 teachers' ideas, feelings and attitudes regarding language assessment; thus, it should not be generalized to all language teachers. Moreover, the themes and codes derived from the data are restricted to the participant teachers' experiences and context-specific problems in their institutions. It would have been better if more teachers from various universities had participated this study. Finally, it would have been better if the views of all sides could have been investigated such as the heads, colleagues, and students. Then, it would have been a more comprehensive study looking into this phenomenon from various lenses.

\section{Declaration of Conflicting Interests and Ethics}

The author declare no conflict of interest. This research study complies with research publishing ethics. The scientific and legal responsibility for manuscripts published in IJATE belongs to the author.

\section{ORCID}

Elcin Olmezer Ozturk (D) https://orcid.org/0000-0001-7743-6361

\section{REFERENCES}

Alderson, J. C. (2005). Diagnosing foreign language proficiency. Continuum.

Baker, B. A., \& Riches, C. (2017). The development of EFL examinations in Haiti: Collaboration and language assessment literacy development. Language Testing, 35(4), 557-581. https://doi.org/10.1177/0265532217716732

Banat, H. (2018). Policy makers, assessment practices, and ethical dilution. In T. Ruecker, \& D. Crusan. (Eds.). The politics of English second language writing assessment in global contexts. (pp. 58-65). Routledge 
Calderhead, J. (1996). Teachers: Beliefs and knowledge. In d. C. Berliner, \& R. C. Calfee (Eds.), Handbook of Educational Psychology (pp. 709-725). Macmillan.

Campbell, Y., Murphy, J. A., \& Holt, J. K. (2002). Psychometric analysis of an assessment literacy instrument: Applicability to preservice teachers. Paper presented at the meeting of the Mid-Western Educational Research Association, Colombus, OH.

Coombe, C., Troudi, S., \& Al-Hamly, M. (2012). Foreign and second language teacher assessment literacy: Issues, challenges, and recommendations. In C. Coombe, P. Davidson, B. O'Sullivan, \& S. Stoynoff. (Eds.). The Cambridge guide to second language assessment. (pp. 20-29). Cambridge University Press.

Creswell, J. W. (2012). Educational Research: Planning, conducting, and evaluating quantitative and qualitative research. Pearson Education.

Davies, A. (2008). Textbook trends in teaching language testing. Language Testing, 25 (3), 327-347. https://doi.org/10.1177/0265532208090156

Dornyei, Z. (2007). Research methods in applied linguistics. Oxford University Press.

Falsgraf, C. (2005, April). Why a national assessment summit? New visions in action. National Assessment Summit. Meeting conducted in Alexanderia, Va. Retrieved from: http://www. nflrc.iastate.edu /nva/word documents/ assessment 2005/ pdf Insap introduction.pdf

Fulcher, G. (2012). Assessment literacy for the language classroom. Language Assessment Quarterly, 9 (2), 113-132. https://doi.org/10.1080/15434303.2011.642041

Hatipoğlu, Ç. (2015). English language testing and evaluation (ELTE) training in Turkey: Expectations and needs of pre-service English language teachers. ELT Research Journal, 4 (2), 111-128. https://dergipark.org.tr/en/pub/eltrj/issue/28780/308006

Herrera, L. \& Macias, D. (2015). A call for language assessment literacy in the education and development of teachers of English as a foreign language. Colomb. Appl. Linguist. J., 17(2), 302-312. http://dx.doi.org/10.14483/udistrital.jour.calj.2015.2.a09

Inbar-Lourie, O. (2008). Constructing a language assessment knowledge base: A focus on language assessment courses. Language Testing, 25 (3), 385-402. https://doi.org/10.117 7/0265532208090158

Jacobs, L. C. \& Chase, C. I (1992). Developing and using tests effectively: A guide for faculty. Jossey-Bass.

Katz, A. (2012). Linking assesment with instructional aims and learning. The Cambridge guide to second language assessment. In C. Coombe, P. Davidson, B. O'Sullivan, \& S. Stoynoff. (Eds.). The Cambridge guide to second language assessment. (pp. 66-73). Cambridge University Press.

Lam, R. (2015). Language assessment training in Hong Kong: Implications for language assessment literacy. Language Testing, 32(2), 169-197. https://doi.org/10.1177/0265532 214554321.

Leung, C. (2014). Clasroom-based assessment issues for language teacher education. In A. J. Kunnan (Ed.), The Companion to Language Assessment, (pp. 1510-1519). Wiley Blackwell.

Malone, M. E. (2013). The essentials of assessment literacy: Contrasts between testers and users. Language Testing, 30 (3), 329-344. https://doi.org/10.1177/0265532213480129

McCafferty, A. S., \& Beaudry, J. S. (2018). Teaching strategies that create assessment-literate learners. Corwin.

McNamara, T., \& Roever, C. (2006). Language testing: The social dimension. Blackwell.

Mede, E., \& Atay, D. (2017). English Language Teachers' assessment literacy: The Turkish context. Dil Dergisi, 168 (1), 1-5. https://dergipark.org.tr/tr/download/article-file/780021 
Mertler, A. C. (2003). Secondary teachers' assessment literacy: Does classroom experience make a difference?. American Secondary Education, 33(1), 49-64. https://www.jstor.org /stable/pdf/41064623.pdf

Mertler, C. A., \& Campbell, C. (2005). Measuring teachers' knowledge and application of classroom assessment concepts: Development of the assessment literacy inventory. Paper presented at the annual meeting of the American Research Association, Montreal, Quebec, Canada. https://eric.ed.gov/?id=ED490355.

O'Loughlin, K. (2013). Developing the assessment literacy of university proficiency test users. Language Testing, 30 (3), 363-380. https://doi.org/10.1177/0265532213480336

Ölmezer-Öztürk, E., \& Aydın, B. (2019). Investigating language assessment knowledge of EFL teachers. Hacettepe University Journal of Education, 34(3), 602 -620. https://doi.org/10. 16986/HUJE.2018043465

Plake, B. S. (1993). Teacher assessment literacy: Teachers' competencies in the educational aasesment of students. Mid-Western Educational Researcher, 6 (1), 21-27.

Popham, W. J. (2006). All about accountability / Needed: A dose of assessment literacy. Educational Leadership, 63(6), 84-85. http://www.ascd.org/publications/educationallea dership/mar06/vol63/num06/Needed@-A-Dose-of-Assessment-Literacy.aspx

Popham, W. J. (2009). Assessment literacy for teachers: Faddish or fundamental? Theory Into Practice, 48, 4-11. https://doi.org/10.1080/00405840802577536

Popham, W. J. (2011). Assessment literacy overlooked: A teacher educator's confession. The Teacher Educator, 46 (4), 265-273. https://doi.org/10.1080/08878730.2011.605048.

Popham, W. J. (2018). Assessment literacy for teachers in a hurry. Alexandria, VA: Association for Supervision and curriculum Development.

Purpura, J. E. (2016). Second and foreign language assessment. The Modern Language Journal, https://doi.org/10.1111/modl.12308

Schafer, W. D. (1993). Assessment literacy for teachers. Theory into Practice, 32 (2), 118-126. https://www.jstor.org/stable/1476329?seq=1\#metadata_info tab_contents

Shepard, L. A. (2000). The role of assessment in a learning culture. Educational researcher, 29 (7), 4-14. https://doi.org/10.3102/0013189X029007004

Stiggins, R. J. (1991). Assessment literacy. Phi Delta Kappan,72, 534-539. https://www.jstor.org/stable/20404455

Stiggins, R. J. (1995). Assessment literacy for the 21st century. Phi Delta Kappan, 77 (3), 238245. https://www.jstor.org/stable/20405538

Stiggins, R. J. (2010). Essential formative assessment competencies for teachers and school leaders. In H. L. Andrade, G. J. Cizek (Eds.), Handbook of formative assessment, (pp. 233-250). Taylor \& Francis.

Şahin, S. \& Hatipoğlu, Ç. (2019). An analysis of English language testing and evaluation course in English language teacher education programs in Turkey: Developing language assessment literacy of pre-service EFL teachers. (Unpublished PhD Dissertation). Middle East Technical University.

Tao, N. (2014). Development and validation of classroom assessment literacy scales: English as a Foreign Language (EFL) teachers in a Cambodian Higher Education Setting. (PhD thesis). Victoria University.

Tsagari, D. \& Vogt, K. (2017). Assessment Literacy of Foreign Language Teachers around Europe: Research, Challenges and Future Prospects. Papers in Language Testing and Assessment, 6(1), 41-64. http://www.altaanz.org/uploads/5/9/0/8/5908292/5.si3tsagarivo gt final formatted proofed.pdf

Vogt, K. \& Tsagari, D. (2014) Assessment literacy of foreign language teachers: Findings of a European study. Language Assessment Quarterly, 11 (4), 374-402. https://doi.org/ $\underline{10.1080 / 15434303.2014 .960046 .}$ 
Volante, L., \& Fazio, X. (2007). Exploring teacher candidates' assessment literacy: Implications for teacher education reform and Professional development. Canadian Journal of Education, 30 (3), 749-770. https://journals.sfu.ca/cje/index.php/cjerce/article/view/2973 